\title{
Influence of Motivation on Students' Academic Achievement in the Teaching of Junior Secondary Three Social Studies in Jalingo Metropolis
}

\author{
Lawrence Okoro \\ Social Science Education, Political Science Unit, University of Nigeria, Nsukka, Enugu State
}

\begin{abstract}
This study aimed to ascertain Influence of Motivation on Students' Academic Achievement in the Teaching of JSS III Social Studies in Jalingo Metropolis Taraba State. Three research questions were raised to guide the study, and descriptive survey research design was used for the study. The target population was 3150 students covering all the 17 public secondary Schools across Jalingo metropolitan. 320 respondents were randomly sampled from five selected Junior Secondary Schools, and a 30-item research instrument, based on 4-point Likert scale, tagged Motivation for Academic Achievement Questionnaire (MAAQ), developed by the researcher and dully vetted by three specialists in measurement and evaluation, guidance and counselling and educational psychology in the Faculty of Education of the University, was used for data collection. Test-rest was used to ascertain reliability of the research instrument using Pearson Product Moment Correlation technique which yielded a coefficient of 0.67. The data collated was analysed using simple frequency count and mean, and the decision mean point was 3.00. It was concluded that intrinsic and extrinsic motivation in a proper blend has the potency to improve students' academic achievement in social studies. The study finally recommends among others that, students should be conscientised as well as be empowered to realize that they play the most important role in motivating themselves first, before anyone else; and also social studies alongside other teaching subject areas be made interesting so as to arouse and sustain students' interests and enhance learners' achievement motivations.
\end{abstract}

Keywords: Motivation, Influence, Students' Academic Achievement, Social Studies, Teaching, Jalingo Metropolis

DOI: $10.7176 / \mathrm{JEP} / 12-1-05$

Publication date: January $31^{\text {st }} 2021$

\section{Background to the Study}

Educational psychologists have long recognized the importance of motivation for supporting students' learning, and societies all over the world have used education as an instrument for the achievement of their national interest and objectives. Education is an instrument par excellence for effective national development. It fosters the worth and development of the individual, for the individual's sake and for the general development of the society Federal Republic of Nigeria (FRN), in the National Policy on Education (2017). It therefore, calls for functional education for the promotion of a progressive and united country like ours. School programmes need to be relevant, practical and comprehensive, while interest and ability should determine the individual's direction in education. In Nigeria for example, in order to achieve the goals and objectives of education, the government set up three levels of education: primary education, secondary education and tertiary education (FRN, 2017). Secondary education (which is the main area of this study) is the second level of education in Nigeria. According to the Federal Republic of Nigeria in the National Policy on Education (2017), secondary education is the education children receive after primary education and before the tertiary stage. The goals of secondary education are to prepare the individual for Useful living within the society, and Higher education. Looking at the number of students that pass out from secondary school each year, one may say that secondary education is trying to fulfill these obligations for establishing it (Uwadiae, 2006). But on the other hand, considering the quality of those students that graduate every year, it appears secondary education is not realizing the goals and objectives for which it is set up (Uwadiae, 2006). This loophole in our secondary education is associated to lack of motivation among other factors (Awanbor, 2005; Rusillo \& Arias, 2004). Students who lack sufficient level of academic motivation exhibit a frail and puny drive towards the pursuit of academic goals also manifest signs and symptoms of indifference and apathy towards school. Majority of such students, if not all, engage in examination malpractice (Awanbor, 2005), and other sorts of deviance to examination rubrics (Daniel, 2015).

What then is motivation? Etymologically, motivation is a concept that has its root from the Latin words "Motare" (which means to shake or stir), and "Motivus" (which means stirred or moved in the same way or, that which makes an individual do something or makes them move). It is defined by Broussard and Garrison (2004) as the attribute that moves us to do or not to do something. Brown (n.d) defined it as what gets one going, keeps one going, and determine where one is to go. In a simpler parlance, Guay, Channel, Ratelle, Marsh, Larose, \& Boivin, (2010) refers to motivation as the reasons underlying behaviour. These scholastic views to motivation imply that motivation is a driving force that causes change from desire to trying to achieving. 
Psychologists have noted that motivation can direct behaviour towards particular goals, lead to increase effort and energy, increase intuition of, and persistence in activities, enhance cognitive processing, determine what consequences are reinforcing and lead to improved performance (Lai, 2011). This implies that motivation is a wider concept. Therefore, the specific kind of it that is studied in the specialized setting of education differs quantitatively from the general form of motivation studied by psychologists in other fields. On this premise, Pintrich and Zusho (2002) define academic motivation as the internal process that instigate and sustain activities aimed at achieving specific academic goals. Self-determination theorists (Ryan \& Deci, 2000) posit that, academic motivation is multidimensional in nature, and it's comprised of two major types of motivation namely intrinsic motivation and extrinsic motivation (Deci \& Ryan, 2002).

In their words, Ryan and Deci (2000) defined intrinsic motivation as "the inherent tendency to seek out novelty and challenges, to extend and exercise one's capabilities, to explore, and to learn". They expounded further that intrinsic motivation is a force that is driven by an interest or enjoyment in the task itself, and exists within the individual rather than relying on external pressures or a desire for reward (Lai, 2011). It is a force within the individual which is not tied to the environment. That is to say, motivation is intrinsic when the drive to do something comes from within an individual rather than from the environment. For instance, if a student derives satisfaction and inner pleasure from the studying of social studies and not merely because of any prompting from teachers or parents, they are said to be intrinsically motivated. Extrinsic motivation on the hand, involves undertaking an activity that results in a separable outcome (Ryan \& Deci, 2000), an activity that may not be inherently enjoyable or interesting. It refers to a situation whereby the drive to do something comes from the outside i.e. within the environment other than from the individual.

To make the teaching and learning of social studies interesting, there is need to use strategies and materials that will make the instruction lively, fascinating, absorbing and adventurous as much as possible. As a matter of semantics, Social Studies like other social science concepts has no universally accepted definition as there is myriads of definitional perceptions. In the words of (Lawal \& Oyele, 2003) social studies is a value-laden discipline. Frost and Rowland (1969) defined social studies as essentially the studies of human relationship, like human to human, human to institutions, human to physical environment and human to value system. Quartey (1984) defined it as a "study that equips the youth with tools necessary in solving personal and community related problems". Osakwe and Itedjere (2005) refer to social studies as an organized integrated study of man and his environment, both physical and social. The National Council for Social Studies in the United States of America officially defined social studies as "An integrated study of the social sciences and humanities to promote civic competence and help young people develop the ability to make informed and reasoned decisions as citizens of culturally diverse, democratic society in an interdependent world" (NCSS, 1992). Lawal and Oyeleye, (2003) described Social Studies as a discipline which attempts to modify or change the learners behaviour in the direction of acceptable values and attitudes through a process of studying human beings relationship with his or her environment and with the desire to provide solutions to various complementing problems in order to ensure his/her survival, having been equipped with the necessary tools such as value, attitudes, skills and knowledge. Thus, from the foregoing, it suffices to say that social studies is basically a discipline that deals with 'man' and his 'social milieu' cum his problem of survival in society. That is the study of man in his society. In fact Lawal and Oyeleye, (2003) noted that social studies are more inter-disciplinary, more concerned with skills development and more normative because it covers such other areas as Anthropology, Economics, Geography, Health Education, History, Law, Medicine, Philosophy, Political Science, Psychology and Religious Studies among others.

Thus, the teaching of social studies means exposing learners to social studies content using the appropriate strategies and techniques that are capable of promoting in them, the ethnics of good and responsible citizenship. Also, effective teaching of social studies would assist learners in the appreciation of the contribution of individuals and groups to human changing cultural heritage. The teacher is charged with the responsibility of delivering content areas that promote a balance, between patriotism and citizenship so as to train up individuals who can stand the test of time as teachers, traders, engineers, doctors, bankers, politicians and the like they choose to become, thereby making them socially relevant, economically viable and politically honest in a rapidly changing world.

The goal and objective of Social Studies Programme in Nigeria among others include;

i. Developing well informed and responsible citizens

ii. Developing children who possess the ability to deal with questions of what ought to be? And what can I do about it?

iii. Building attitudes and values that are consistent with society's desires.

iv. Developing in learners skills such as those involved in reporting, acquiring and classifying data (reflective thinking/inquiring skills).

v. Developing the appreciation and understanding of learners' cultural heritage and its role in contemporary society,

vi. To develop a positive sense of cooperation, social and moral responsibility. 
vii. To foster a basic understanding of the nation's process of development through the study of the physical environment and social/ political institutions as well as the national economy as it relates to other economies.

viii. To promote national identity and integration within Nigeria varied historical origin and inter-related culture and

ix. To develop an understanding of the world of science and of inter-relationship between nations among others The Federal Republic of Nigeria (FRN) in the National Policy on Education (1998), in section 1 (2) emphasizes that the quality of instruction in social studies at all levels has to be oriented towards inculcating values which includes;

i. Respect for the worth and dignity of individual

ii. Faith in man's ability to make interpersonal and human relations

iii. Moral and spiritual values in interpersonal and human relations

iv. Share responsibility for the common of society value

v. Respect for the dignity of labour and

vi. Promotion of the emotional, physical and psychological health of all children.

A wealth of empirical evidence substantiating and linking motivation to learning outcomes abound. For instance, Oriahi (2009) investigated the Influence of Motivation on Student's Academic Performance, and developed four research questions and four null hypotheses to guide the study, using a survey design. The sample comprised of 720 respondents comprising 640 students and 80 teachers randomly drawn from 16 secondary schools and 15 people from different works of life. Researcher's self-developed questionnaire tagged Influence of Motivation on Academic Performance (IMOAP) for secondary school students and teachers dully vetted by specialists in measurement and evaluation, guidance and counselling and educational psychology was used for data collection. Data collected were analysed using simple percentage. The result showed that: Motivation of students is very important for better out-put in the academic pursuit. Students' motivation has high positive correlation in their academic achievement. And there is also a significant relationship between school environment and students' motivation. The study recommended that students should be made to understand that their destiny lies in their own hands and should be conscientious and empowered to realize that no matter what anybody does to motivate them; they (the students) play the most important role of motivating themselves. And that trained teachers who are interested in students improvement should be employed to teach.

The Impact of Motivation on Student Academic Achievement and Learning Outcome in Mathematics among Secondary School Students in Nigeria was conducted by Tella (2007), with a sample of 450 participants using expost-facto research design and motivation for academic preference scale $(\infty=0.82)$ as a measuring instrument and a research instrument tagged Achievement Test in Mathematics (ATM). The result revealed that there is significant difference in the academic achievement of highly motivated and lowly motivated students in mathematics. That, highly motivated students perform better academically than the lowly motivated ones, and so recommended that teachers should try as much as possible to motivate their students in the course of instruction. Also the Effect of Motivation on Students' Achievement in Social Studies was investigated by Abdu-Raheem (2011). The study consisted of 240 Junior Secondary School Class II and adopted quasi-experimental, pre-test, post-test control group design. Simple random sampling was used to select 40 students each from six selected secondary schools in Ekiti State, and the instrument used for the study was the Social Studies Achievement Test (SSAT) designed by the researcher. The data were analyzed using t-test and ANOVA statistical tools. The result indicated that there was a significant difference between the pre-test and achievement mean scores of students in the experimental and control group. It was concluded that motivation is the basic, in addition to the choice teaching method in improving students' achievement in social studies. In the same vein, Olujide, Olugori and Olufunke (2012) examined the effect of motivation on text performance of first year Covenant University students, Ota, Ogun State. The study adopted pre-text, post-text experimental design. Data for the study were obtained from 60 students with age range 15 and 18 years. Participants were randomly assigned to three conditions using independent group design. The result shows a significant difference between the result of the unrewarded students in the control group and students rewarded with verbal praise in the experimental group. The study justifies the importance of motivation on test performance by recommending that to improve students' academic achievement, teachers are encouraged to motivate their students. A descriptive survey on the Causes of Poor Academic Achievement in Northern Nigeria was carried out by Yoloye as cited in Tella (2007). He reported that majority of the children who were labeled as backward or unintelligent to school were good but were handicapped by physical characteristics and disease. Burnett (2011) in his research on primary school pupils preference for teachers praise and feedback was measured based on praise Attitude Questionnaires (PAQ), with a sample of 747 pupils (age range from 8-12 years) result indicated that $91 \%$ of the pupils preferred to be praised (i.e. be given a extrinsic motivation), $9 \%$ reported that they never wanted praise. Also $84 \%$ preferred to be praised for trying hard or putting in effort (i.e. effort attribution), rather than having good ability (i.e. ability attribution).

Also in Tella (2007) Harju and Eppler investigated the relationship among College Students Learning and Achievement, drawing on questionnaire data from ages 17-22 of College Students totaled 312. It was reported 
that students who had a learning profile motivation had better performance. Cheung, in Tella (2007) hypothesized, that conceptions of success of achievement goal affect both the inclination to and actual performance. This was tested in a sample of 673 Chinese adolescents, and sex differences were found in the conception of success. A research conducted by Shoukat, Zubair, Fahad, Hamid and Awais (2013) on the Factors Contributing to the Students' Academic Performance in Pakistan with a sample of 100 students, using correlative and descriptive analysis, their findings revealed that age, guardian's economic status, daily study hours and self motivation significantly contribute to the academic achievement of students.

In support of the above empirical studies, there are various theories of motivation, howbeit, this study is anchored on B.F. Skinner (1904-1990) Conditioning theory, Maslow's (1908-1970) hierarchy of needs theory and Edward L. Deci and Richard M. Ryan (2000) self-determination theory. The conditioning theory of Skinner emphasizes that learning can only be achieved through reward and punishment for behaviour through positive reinforcers, negative reinforcers, and punishment. Positive reinforces (also known as rewards) are consequences that increase the probability of a given behaviour they were made contingent on e.g. praise or direct reward. Negative reinforcers, are consequences that decrease the probability of a given behaviour by removing or reducing some negative external stimuli e.g. a school child being told they will lose recess privilege if they talk out of turn in class (in both cases of positive and negative reinforcement, behaviour increases). Punishment on the other hand, refers to unpleasant consequences that decrease the probability of a given behaviour. It can be positive or negative. It is positive when it involves the presentation of an unfavourable outcome in order to weaken the response it follows, making the behaviour less likely to happen in future e.g. A teacher reprimanding a student for sleeping in the class during lesson; performing very poor on a given home work, etc. (Kendra, 2010; Hockenbury \& Hockenbury, 2007; Skinner, 1974). It is negative when unfavourable outcome is removed after behaviour occurs, resulting the behaviour happening less often in future e.g. teacher relegating a class monitor for some period of time or completely assigning someone else the responsibility other than the default student; stripping off a student from their prefect posts, etc. (it is sometimes called punishment by removal). In both of these cases of punishment, the behaviour decreases (Kendra, 2010; Gershoff, 2002).

This theory is relevant to this study and this is because, rewarding a good performance creates in a student the intrinsic motivation to improve. Under this framework, the teacher's job is clear; to grade performances accordingly and awards praises to desired behaviour and reprimand or punish wrong behaviours. In the teaching of social studies such will motivate students to learn and increase their academic achievement. Abraham Maslow hierarchy of needs theory states that, human beings have certain basic inborn needs which they strive to fulfill. He described these human needs as biological needs. To Maslow, every need arises from an imbalance or disequilibrium between what human nature deems necessary for the survival of the individual and what the person's environment provides. When the environment provides what they need, then a state of balance or equilibrium will be established. He proposes five types of human needs in a hierarchy which reflect the sequence in which the needs should be fulfilled namely; Physiological Needs, Safety Needs, Love Needs, Self Esteem, and Self Actualizations.

According to the theory, a child must be free from hunger, pain and fear for his physical safety, so that he/she could have that sense of belonging and be motivated to learn effectively. As such, the teaching and learning of social studies entails that parents and teachers should ensure the physiological and safety needs of learners so that they can attain high academic achievement in pursuit towards self actualization (Faundai, 2012).

This theory is relevant to this study, on the basis that, teaching and learning cannot take place in an unsafe environment. It is only when a learner is physiologically safe that they are ready to learn, and it is only when a learner develops that sense of belonging through the enabling environment created by the teacher that they can concentrate to learn, which in turn leads to an attainment of academic achievement.

Edward L. Deci and Richard M. Ryan (2000) self-determination theory advocated that the more the selfdetermination or intrinsic motivation, the better are the observed outcome/motivation to achieve (Ryan \& Deci, 2000), derived from deep learning, high academic achievement (Vansteenkiste \& Soenens 2005), better adjustment and positive well-being (Black \& Deci, 2000; Levesque, Zuehlke, Stanek \& Ryan, 2004). This theory was mainly to support human natural or intrinsic tendencies to behave in effective and healthy way. It focuses on the degree to which an individual's behaviour is self-motivated and self-determined (Deci \& Ryan, 2002). It differentiates between motivation that originates within an individual (known as intrinsic motivation) and the motivation that originates from external sources (known as extrinsic motivation). Thus, the theory is relevant to this study on the basis that based on the way social studies teachers ensure healthy and disciplined classroom climate for effective teaching and learning, students would develop that self-determination, (intrinsically) towards improved academic achievement.

Thus from the foregoing, it is evident that in education, motivation has several influences on students learning and behaviour and it is notably an essential factor for academic achievement but (Elliot \& Dweck, 2005). On the other hand, an unmotivated teaching and learning environment does not motivate students towards learning social studies. Howbeit, whose contractual obligation is it to motivate students? 


\subsection{Statement of the Problem}

The problem of effective teaching and learning of social studies in Junior Secondary Schools in Jalingo has become a sensitive issue that needs urgent attention. For good academic achievement to be ensured among students in social studies, motivation is a sine qua non. As a matter of fact, the academic underachievement of students is attributed to among other factors lack of interest in studies due to inadequate motivation, the adopted pedagogy by the teacher, the nature of classroom management and poor teacher/student relationship. The absence of this motivation has led to truancy among students, school drop-outs, examination malpractice, poor performance and academic underachievement. This impediment has been militating against effective instructional delivery and academic achievement in social studies in Jalingo metropolitan. How to curb this menace through motivation is the concern of this research. Hence, the study investigates the Influence of Motivation on Students' Academic Achievement in the Teaching of JSS III Social Studies in Jalingo Metropolis.

It is believed that the result from this study will assist the Ministries of Education to embark on the employment of qualified and professional teachers in our secondary schools as well as take further step to send teachers for in-service training in order to update their knowledge in the area of motivation. This study is hoped to aid educational planners, authors, experts and curriculum designers as justification for incorporating dimensions of motivation into the secondary school curriculum in Nigeria.

\subsection{Purpose of the Study}

The purpose of this study is to;

1. determine the influence of intrinsic motivation on students' academic achievement in Jalingo.

2. determine the influence of extrinsic motivation on students' academic achievement in Jalingo.

3. determine the influence of intrinsic and extrinsic motivation on the teaching of JSS III social studies in Jalingo.

\subsection{Research Questions}

To find out the influence of motivation on students' academic achievement in the teaching of JSS III social studies in Jalingo, the following research questions are raised:

1. What is the influence of intrinsic motivation on academic achievement of students in Jalingo?

2. What is the influence of extrinsic motivation on the academic achievement of students in Jalingo?

3. What is the influence of intrinsic and extrinsic motivation in the teaching and learning of social studies in Jalingo?

\section{METHODOLOGY}

\subsection{Research Design}

This study adopted the descriptive survey research design, a planned collection of data at a particular point in time for the purpose of describing the nature of existing conditions. The researcher opted for descriptive survey so as not to manipulate any variable.

\subsection{Population}

The target population for the study is 3150 , made up of all the Junior Secondary Schools (JSS III) Classes across the 17 Government owned Junior Secondary Schools in Jalingo metropolitan, Taraba State. (Source: Education Resource Center, Jalingo, 2014).

\subsection{Sample and Sampling}

The sample consisted of 320 Junior Secondary School Students, Class 3 (i.e. JSS III) drawn from the five selected schools across Jalingo metropolitan. A stratified random sampling was used for the study. A stratified sampling is a combination of random and purposive sampling and to a large extent avoids the abnormalities of random sampling, and the bias of purposive sampling. This was done by writing the names of the 17 Public Secondary Schools in Jalingo Metropolitan on separate pieces of papers; collect them in cellophane and picked randomly one after another with replacement. The strata introduced School type, Gender, and School location as shown in Table 1 below. Participants' ages ranged from 11 - 13 years, and were 160 males and 160 females evenly distributed by the sample size. 
Table 1:

Schools used for the study

\begin{tabular}{lccc}
\hline Schools & Students' Sample & Total \\
& Male & Female & \\
\hline Government Day Junior Secondary School Nukkai & 32 & 32 & 64 \\
Government Junior Science Secondary School & 32 & 32 & 64 \\
Government College & 32 & 32 & 64 \\
Magami Government Day Junior Secondary School & 32 & 32 & 64 \\
Government Day Secondary School Model & 32 & 32 & 64 \\
\hline & 160 & 160 & 320
\end{tabular}

\subsection{Instrumentation}

The research instrument tagged Motivation for Academic Achievement Questionnaire (MAAQ) designed by the researcher was used to gather data from the respondents. Items in the instrument were adopted from the Motivation for Achievement Study Scale (MASS) by Osiki (2001). The research instrument was designed to indicate the degree of agreement from the respondents. The instrument consisted of two sections- 'A' and 'B'. Section 'A' required the participants' demographic information while section ' $\mathrm{B}$ ' elicits participants' responses on the items based on the contents. The instrument is a 30-item of 4-Likert type format, with responses ranged from Strongly Agree to Strongly Disagree.

\subsection{Validation of Instrument}

The research instrument was face and content validated by three experts in Faculty of Education of the University.

\subsection{Reliability of Instrument}

Test-retest was used to ascertain the reliability of the instrument using Pearson Product Moment Coefficient technique which yielded a correlation coefficient value of 0.67

\subsection{Method for Data Analysis}

Data collected were analysed using simple frequency count, and mean. The decision point was 3.00. The implication is that a mean value above 3.00 will be considered as "agree" and value below 3.00 as "disagree".

\section{DISCUSSION}

Research Question 1: What is the influence of intrinsic motivation on students' academic achievement in Jalingo?

Table 2: Showing the frequency and mean response from respondents on Influence of Intrinsic Motivation on Students' Academic Achievement

$\begin{array}{lccc}\mathrm{S} / \mathrm{N} & \text { Item Statement } & \begin{array}{c}\text { Students' Response } \\ \text { (Frequency) }\end{array} & \begin{array}{c}\text { Mean } \\ \text { (X) }\end{array}\end{array}$

SA A D SD

1. I prefer social studies to other subjects

$\begin{array}{cccccc}126 & 86 & 92 & 16 & 3.01 & \text { Agree }\end{array}$

3. I study very well to pass my social studies exams

4. Social studies is a simple subject

$\begin{array}{llllll}16 & 77 & 109 & 118 & 1.97 & \text { Disagree }\end{array}$

5. I derived pleasure in studying my Social study text books

6. My social studies teacher can teach very well

7. I like the way my social studies teacher used to teach

$\begin{array}{llllll}186 & 119 & 7 & 8 & 3.51 & \text { Agree }\end{array}$

$\begin{array}{llllll}139 & 108 & 57 & 18 & 3.16 & \text { Agree }\end{array}$

I do not like to miss social studies classes

$\begin{array}{llllll}107 & 145 & 32 & 36 & 3.01 & \text { Agree }\end{array}$

9. Social studies lesson is very interesting to me

10. I always discuss social studies topics with my class mate

$\begin{array}{llllll}67 & 36 & 95 & 122 & 2.15 & \text { Disagree }\end{array}$

$\begin{array}{llllll}51 & 51 & 102 & 116 & 2.43 & \text { Disagree }\end{array}$

$\begin{array}{llllll}36 & 67 & 99 & 118 & 2.06 & \text { Disagree }\end{array}$

$\begin{array}{llllll}138 & 110 & 36 & 36 & 3.09 & \text { Agree }\end{array}$

Respondents agree with items statements 1, 3-5, and 9 but disagree with item statements 2, 6-8, and 10 in the table.

It is pellucid from the table that ten item statements were presented to guide the research question. Item one indicates that 126 respondents strongly agree with the statement. From the mean value 3.01, we agree with the 
statement, based on the acceptable decision point at the mean value of 3.00 and above, therefore, we agree with the statement. This shows that a student's likeness towards social studies (vis-à-vis other teaching subjects) is based on the genuine interest they have on it which arises from intrinsic motivation and dependent on the extent they are intrinsically motivated. Item three shows that 186 respondents strongly agree with the statement at decision mean value of 3.51 showing that success or excellence and academic achievement are first, the function of intrinsic motivation. Item four indicates that 139 strongly agree with the statement at decision mean value 3.16 showing that the level of motivation a student attaches to a subject makes the subject appear easy and simple unlike when there is no intrinsic motivation at all. In item five 145 respondents agree with the statement, at mean value 3.01, indicating that high level of intrinsic motivation stimulates better study habit towards high academic achievement and Item nine shows that 138 respondents also strongly agree with the statement, at mean value 3.09 indicating variation in the level of intrinsic motivation, depending on personal interest. Therefore, it suffices to say that on research question one, the responses to item statements 1, 3, 4, 5 and 9 strongly agree that intrinsic motivation has a positive influence on students' academic achievement in jalingo.

This tally with the opinions of Rusillo and Arias (2004) that there is significant level of academic motivation on learning at school; Oniyama and Onyiama (2005) that students play major role in motivating themselves for better academic achievement; Covington (2000) on the need for students to promote and protect their sense of personal value; and Ryan and Deci (2000) that the more autonomous motivation (i.e. intrinsic motivation) the better are the observed outcome, and high academic achievement (Varisteenkiste \& Soenen 2005). Whereas the responses to item statements 2, 6, 7 and 10 strongly disagree, this implies that some social studies teachers are not doing enough to enhance academic achievement.

Research question 2: What is the influence of extrinsic motivation on student academic achievement in Jalingo?

Table 3: Shows the frequency and mean response from respondents on Influence of Extrinsic Motivation on Students' Academic Achievement in Jalingo.

\begin{tabular}{llccc}
\hline $\mathrm{S} / \mathrm{N}$ & Item Statement & $\begin{array}{c}\text { Students' Response } \\
\text { (Frequency) }\end{array}$ & $\begin{array}{c}\text { Mean } \\
\text { (X) }\end{array}$ & \\
& SA A A D SD & & \\
& & SD &
\end{tabular}

11. Our teacher always reward us with Praise when we answer questions on social studies in the class

$\begin{array}{rrrrrr}138 & 100 & 46 & 36 & 3.06 & \text { Agree } \\ 135 & 95 & 53 & 37 & 3.03 & \text { Agree } \\ 136 & 97 & 51 & 36 & 3.04 & \text { Agree } \\ 127 & 107 & 47 & 37 & 3.01 & \text { Agree } \\ & & & & & \\ 135 & 100 & 40 & 45 & 3.02 & \text { Agree } \\ 127 & 101 & 77 & 15 & 3.06 & \text { Agree } \\ 91 & 80 & 104 & 47 & 2.68 & \text { Disagree } \\ 151 & 125 & 8 & 36 & 3.22 & \text { Agree } \\ 130 & 129 & 23 & 38 & 3.09 & \text { Agree } \\ & & & & & \\ 133 & 128 & 21 & 38 & 3.11 & \text { Agree }\end{array}$

12. Our teacher do encourage us to study our social studies text books

13. Supports from my parents contribute to my success in social studies

14. Student participate in social studies activities because of the reward they get from it

15. Without rewards students would not participate in academic activities especially in social studies

16. Teacher use rewards to attract students to learn, especially social studies

17. Students do not have interest in school because of difficult academic tasks

18. Sometimes students need discipline to make then serious with their academics

19. The more student are rewarded the more their level of success in social studies

20. Students always expect rewards when they perform well in the social studies class

Respondents agree with item statement 11-16, 18-20 and disagree with item 17 in the table.
On the above table, ten items were also presented to guide research question two. It shows that 138 respondents strongly agree with the statement on item eleven, on the decision mean point 3.06 we agree with the statement showing that when students are not internally motivated, need the extrinsic motivation created by the teacher. Item twelve on the table shows that, 135 respondents strongly agree with the statement. Since the mean value is 3.03, we agree with the statements that teachers do encourage students to study social studies. This shows some level of extrinsic motivation. Item thirteen indicates 136 strongly agree with the statement. At the decision mean value 3.04, we agree with the opinion that supports from parents contribute to students' success. This indicates that motivation is a 'quality' parents, among others must possess if our educational system is to prepare 
young people for improved academic achievement. On item fourteen, 127 respondents strongly agree with the statement and at the decision mean value 3.01, it indicates that extrinsic motivation has positive influence towards the academic achievement of students. Item fifteen on the table shows that 135 respondents strongly agree, at the decision mean value 3.02, it shows that rewards are consequences that increase the probability of a given behaviour they were made contingent on. Item sixteen shows that 127 strongly agree with the statement and on the decision mean value 3.06, we agree with the statement that 'teachers sometimes use rewards to attract students to learn' showing that there is no detrimental effect of reward (extrinsic motivation) on intrinsic motivation. On item eighteen, 125 respondents agree with the statement based on the decision mean value 3.22, we agree with the statement that 'sometimes students need discipline to make them serious with their academics,' showing that, learning is achieved more through reward and punishment for behaviour. Item nineteen indicates that 130 respondents strongly agree with the statement and on the decision mean value 3.09, we agree with the statement that 'the more students are rewarded the more their level of success in social studies'. This shows that the more students are motivated the better their academic achievement, and also what accounts for difference in achievement of an individual in doing something is usually the level of motivation. The twentieth item on the table indicates that 133 respondents strongly agree with the statement and at decision mean value 3.11 , we agree with the statement that 'students always expect rewards when they perform well in social studies classes'. It therefore suffices to say that with the exception of item 17 , all items on the table agree that extrinsic motivation positively influence the academic achievement of students in social studies in Jalngo.

Research Question 3: what is the influence of intrinsic and extrinsic motivation on students' academic achievement in the teaching and learning of social studies?

Table 4: Showing the frequency and mean response from respondents on the Influence of Intrinsic and Extrinsic Motivation on Students' Academic Achievement in the teaching and learning of Social Studies.

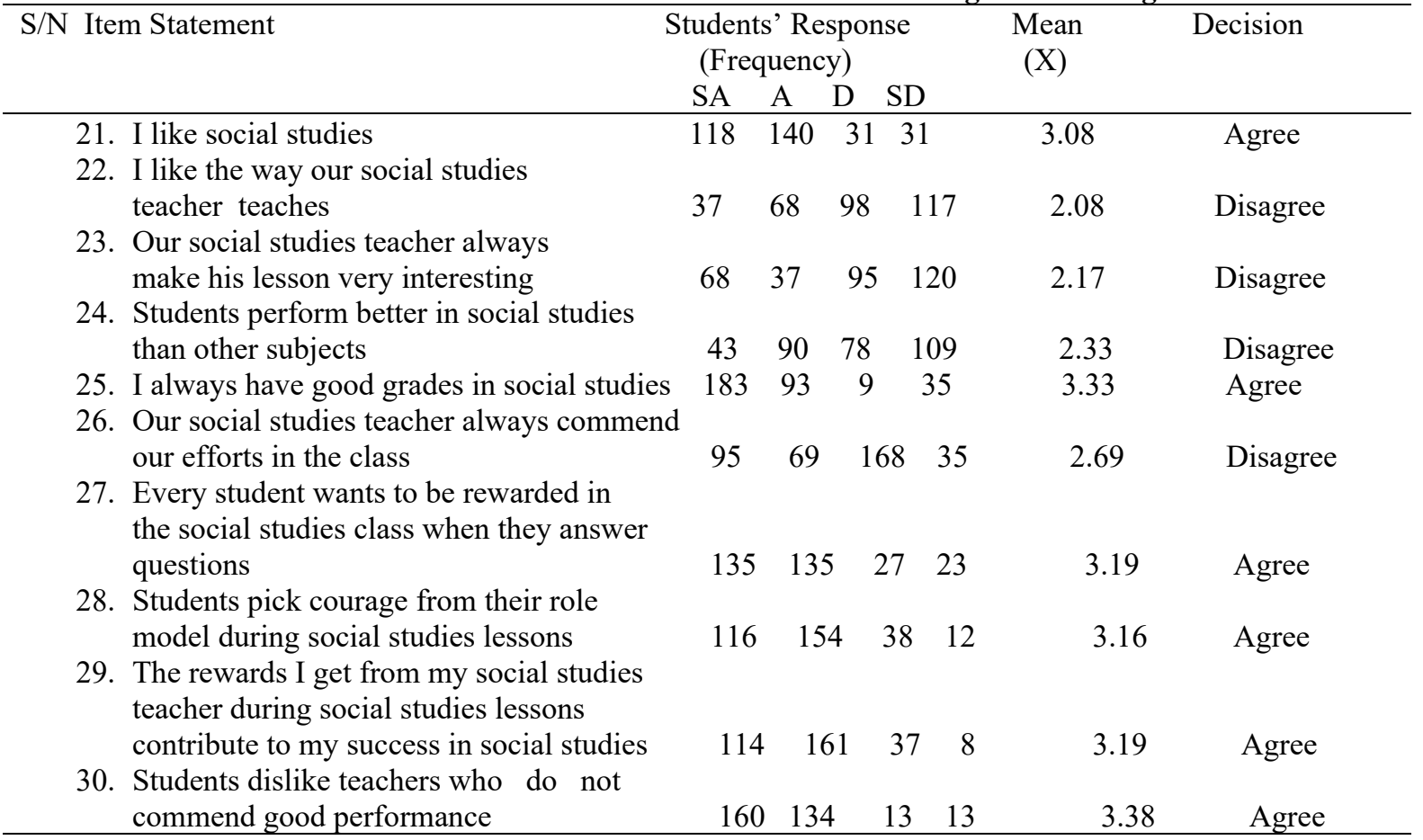

Respondents agree with item statements $21,25,27-30$ and disagree with 22- 24, 26 in the table above.

Ten items were also presented to guide the research question. Item twenty-one on the table shows that, 140 respondents agree with the statement and based on the decision mean value 3.08, we agree with the opinion indicating that genuine interest arises from intrinsic motivation. Item twenty-five indicates that 183 respondents strongly agree with the opinion and at the mean value 3.33 , it is an indication of high level of motivation in the teaching and learning of social studies. Item twenty-seven shows that 135 respondents strongly agree with the statement, based on the mean value 3.19, it shows that rewards are consequences that increase the probability of a given behaviour they were made contingent on; this corroborates B.F. Skinner's conditioning theory (1904-1990). Also the table shows in item twenty-eight that, 154 respondents agree with the statement the mean value is 3.16 , this shows that those who have high achievers as role models in their early life experience would develop the high motivation towards success. Item twenty-nine indicates that 116 respondents agree with the statement, 114 strongly agree to it, at the decision mean value 3.19 indicating that when teachers motivate students, they tend to improve and have high propensity to achieve success in their academics. Finally, item thirty indicates that 134 respondents agree with the statement, 160 strongly agree with the statement and on the decision mean value 3.38, showing that, 
students who lack sufficient level of academic motivation exhibit a weak drive towards the pursuit of academic goals. From the above analysis, it suffice to say that respondents disagree with items 22,23, 24 and 26 at various decision points, but agree with items 21, 25, 27, 28, 29 and 30; this shows that extrinsic and intrinsic motivation have a positive influence on students academic achievement in the teaching of JSS III social students. This corroborates Linnenbrink and Pintrich, (2000) that if teachers decide to extrinsically reward productive students' behaviour, students may find it difficult to extricate themselves from that path; William and Stockdale (2004), Awanbor (2005) that motivating students academically will increase students' academic achievement and Ormnde (2003), as well as Aluede and Omoregie (2005) that both teachers and school organization have great role to play in motivating students for improved academic achievement. It is also in line with self-determination theory of motivation which specifically pointed out types of motivation as intrinsic motivation, which originates within an individual and extrinsic motivation, which originates from external source.

\section{Discussion of Findings}

The findings show that motivation has positive influence on academic achievement of secondary school students in Jalingo. From research question one; the result revealed that success in school subject or academics generally depending on the motivating factors, and the level to which a student is intrinsically motivated determine their level of academic achievement in the subject. This lends an inference that highly motivated students perform better than lowly motivated students. The finding corroborates Oniyama and Oniyama (2005) that students play a major role in motivating themselves for better academic achievement. That is, successful students have significant higher motivation for achievement than unsuccessful students. Similarly, the report by Ryan and Deci (2000) that the more intrinsic motivation, the better are the observed outcome and high academic achievement, lend a good support to the present findings. It suffices to say that the level of academic achievement of a student is a correlate and function of their motivation. Therefore, the contribution or role of intrinsic motivation to success cannot be underrated because it is a factor that can make or mar students' achievement in school.

With regard to the second research question that guides this study, the investigation reveals that secondary school students differ in their academic achievement based on the extent to which they are extrinsically motivated in complementarity to their already existing autonomous (intrinsic) motivation within them. This finding corroborates Aluede and Omoregie (2005) that both teachers and school organization have a great role to play in motivating students for their improved academic achievement. Similarly, the view of Linnenbrink and Pintrich (2000) that students when not internally motivated need situated motivation found in environmental condition that the teacher creates tallies with the findings and also, that if teachers extrinsically reward good behaviours, students may find it difficult to extricate themselves from that path; and Oriahi (2009) that teachers, parents, school administrators and other members of the community must have motivation, to prepare young people adequately for better academic achievement. Therefore, it suffices to say that students who are praised by their teachers are motivated to study harder and achieve more than those who are not. Moreover, parents-assisted home studies and conducive home environment vis-à-vis schools with better organization, good academic facilities, qualified teachers and good learning environment inspire students' motivation towards excellence and high academic achievement. It suffices to conclude that, the finding is a contribution to the existing knowledge in Tella (2007), Olujide, et al. (2012), Yoloye in Tella (2007) and Burnett (2011) and lends an inference that extrinsic motivation is a requisite skill every teacher should possess for effective and efficient instructional delivery.

With regards to the third research question, the research shows that intrinsic and extrinsic motivation influence students' academic achievement in social studies. The both types of motivation are indispensible. This generates an inference that when students express lack of interest in a subject due to amotivation, it affects the way they react or listen to the teacher. Thus, interest arising from motivation and attitude of learners towards a particular subject, matter a lot. This is because positive attitudes and interest learners display, particularly in social studies, serve as an encouragement to the teacher. And this can help the teacher to disseminate his teaching to the best of his ability and knowledge, than resorting to the use of chalk and talk due to learners' lack of interest or negative attitudes. Good impartation of social studies knowledge on the part of the teacher, couple with students' interest in the subject and the display of positive attitudes as earlier pointed out, are good motivating factors which when combined together will result to better achievement in social studies. This finding is in line with Tella (2007) who posited that in making instruction interesting in learning social studies, there is need to make use of strategies and materials which will make learning of social studies interesting and adventurous.

\section{Summary}

This study investigated Influence of Motivation on Students' Academic Achievement in the Teaching of JSS III Social Studies in Jalingo Metropolis Taraba State. Based on the data collated and analysed in the study, the major findings reveal that students perform better and stand the chance to achieve better academically, when they have higher intrinsic motivation. It shows that intrinsic motivation is the major prerequisite to achievement and it is a complement to high Intelligent Quotient (IQ). By implication, students with high intelligent quotient and high 
expectation of success (i.e. intrinsic motivation) in school, do get higher grades and so achieve higher than their peers with even high intelligent quotient and low expectation of success. The findings also indicated that extrinsic motivation has a direct influence on students' academic achievement. It also reveals that encouragement from parents, teachers, peer group and role model contribute significantly to the success of students. Students tend to identify with peers and role model from whom they pick challenges and encouragement. Teachers on the other hand, are facilitators whose main function is to ensure that learners become active participants in their learning and reinforce improved performance of students. Finally, the finding shows that success in school subjects or academics generally, depend on many motivating factors, such as, the complementarity of intrinsic and extrinsic motivation, good instructional facilities, and good learning environment among others.

\subsection{Conclusion}

The study concludes that intrinsic and extrinsic motivation in a proper blend has the potency to improve student's academic achievement in social studies. The both aspects of motivation should be treated each at its quantum merit because they form prerequisite quality that must be possessed by teachers and students in addition to good learning environment for improved teaching and learning and high academic achievement.

\subsection{Recommendations}

Based on the findings, this study recommends the following;

1. Students should be conscientised and empowered to realize that they play the most important role of motivating themselves first, before anyone else, as they are beneficiaries of their own academic pursuit before any other person, and in doing this, individual differences in ability, background and attitude should be borne in mind.

2. Social studies alongside other teaching subject areas should be made interesting, so as to rouse and sustain students' interest, and enhance their achievement motivation.

3. Trained teachers who are skillful in motivation should be employed to teach, and schools should always organize "prize and award giving" programmes, so as to enhance students' motivation towards high academic achievement.

\section{REFERENCE}

Abdu-Raheem, B. O. (2011). Effect of Discussion Method on Secondary School Students' Achievement and Retention in Social Studies. European Journal of Educational Studies, 3(2). 293-301.

Aluede, O. and Omoregie, E. O (2005). Basic Text in Education: Basic Text for Foundation Students (series 1). Agbor Nigeria: Cental Book Ltd.

Awanbor, D. (2005). Credentialing Process in the Nigerian Education System. Being a Keynote address Presented at the First Annual Conference of the Faculty of Education, Ambros Ali University, Ekpoma Nigerin.

Black, A. E., \& Deci. E. L. (2000). The effects of instructors' autonomy support and students' autonomous motivation on learning organic Chemistry: A Self-determination theory Perspective. Science Education, 83, $740-756$

Brown, M. (n.d.). Environmental Influence on Academic Motivation. Retrieved from http//sitemaker.umich.edu/Melissa.brown/home. In Adekeye, A. O., Remu, O. \& Ademuwagun, E. O. (2012). Effects of Motivation on Test Performance of First Year Covenant University Students. Journal of Education and Practice, 3 (13), 65-73

Burnett, P. C. (2001). Elementary Students' Preference for Teacher Praise. Journal Classroom Interaction.

Cheung, C. (n.d.). Conceptions and of Success. Their Correlate with Pro-social Orientation and behavior in Chinese Adolescents. In Tella, A. (2007). The Impact of Motivation on Students' Academic Achievement and Learning Outcomes in Mathematics among Secondary School Students in Nigeria. Eurasia Journal of Mathematics, Science \& Technology Education, 13(2). 149-156.

Covington, M. V. (2000). Goal Theory Motivation and School Achievement: An Integrative Review. Annual Review of Psychology, 51(1). 171.

Daniel, K. A. (2015). Effect of think-pair-share (TPS) and students' teams achievement divisions (STAD) instructional strategies on senior secondary school students' achievement and interest in economics. Unpublished M.Ed Thesis. Social Science Department, University of Nigeria, Nsukka.

Deci, E. \& Ryan, R. (Eds.). (2002). Handbook of Self-determination Research. Rochester, New York: University of Rochester Press.

Education Resource Center (2014). Ministry of Education Jalingo, Taraba State.

Elliott, A. J. \& Dweck, C. S. (2005). Handbook of Competence and Motivation. New York: Guilfor Press.

Frost, J. L. \& Rowland, G. T. (1969). Curricula for the Seventies. Boston: Houghton Mfflin Company.

Fundai, C. M. (2012). "Theories of Learning” an Unpublished Lecture Note Delivered on Human learning on $18^{\text {th }}$ July ; Taraba State University, Jalingo. 
Gershoff, E. T. (2002). Corporal Punishment by Parents and Associated Child Behaviour and Experiences: A Meta- Anlytic and Theoretical Review. Psychological Bulletin, 128(4). 539-579.

Guay, F., Channel, J., Ratelle, C. F., Marsh, H. W., Larose, S. \& Boivin, M. (2010). Intrinsic, Identified, and Controlled Types of Motivation for School Subjects in Young Elementary School Children. British Journal of Educational Psychology, 80(4), 711-735.

Harju \& Epplere in Tella, A. (2007). The Impact of Motivatio on Students Academic Achievement and Learning Outcome in Mathematics among Secondary School Students in Nigeria. Eurasia Journal of Mathematics, Science \& Technology, 3(2). 149-156.

Hockenbury, D. \& Hockenbury, S. E. (2007). Discovering Pychology. New York: Worth Publishers.

Kendra, C. A. (2010). The Everything Psychology Book. New York: Good read.

Lai, E. R. (2011). Motivation: A Literature Review Research Report.

Lawal, M. B. \& Oyeleye, A. S. (2003). Foundations and Principles of Social Studies Education. Lagos: A Triads Associates.

Levesque, C., Zuehlke, A. N., Stanek, L. R., \& Ryan. R. M. (2004). Autonomy and Competence in German and American University Students: A comparative Study based on Self-determination theory. Journal of Educational Psychology, 96, 68-84.

Linnenbrink, E. A. \& Pintrich, P. R. (2000). Motivation as an Enabler for Academic Success. School Psychology Review, 31(3), 313-327.

Luszczynska, A. \& Schwartzer, R. (2005). Social Cognitive Theory. In M. Conner \& P.

National Policy on Education, (2017 th Edn). (2004). Lagos: Nigerian Educational Research and Development Council Press. ISBN: 978-054-217.

Olujide, A. A., Oluyore, A. \& Olufunke, E. A. (2012). Effects of Motivation on Test Performance of First Year Covenant University Students. Journal of Education and Practice, 3(13), 65-73.

Oniyama, H. O. and Oniyama, E. E. (2005). Introduction to Sociology of Education: A Social Psychological Anaysis. Nigeria: Toni-Jode Press.

Oriahi, C. (2009). Influence of motivation on Students' Academic performance. The Social Sciences, 4 (1), 30 36.

Ormrond, J. E. (Eds.). (2003). "Educational Psychology. Developing Learners". New York: Merrill Prentice Hall.

Osakwe, E. O. \& Itedjiere, P. O.(2005). Social Studies for Tertiary Students in Nigeria. Benin.

Osiki, J. O. (2001). Motivation for Academic Study Scale. Ibadan: Stirling-Horden Publisher.

Pintrich, P. R. \& Zusho, A. (2002). The Development of Academic Self-regulation: The Role of Cognitive and Motivational factors. In A. Wigfield \& J. S. Eccles. (Eds.), Development of Achievement Motivation (pp.249284). San Diego, CA: Academic Press.

Quartey, S. M. (1984). A Method for Social Studies Teachers. Lagos: Orits Egwa Ltd.

Rusillo, M. T. C. \& Arias, P. F. C. (2004). Gender differences in academic motivation of secondary school students. Electronic Journal of Research Educational Psychology, 2 (1), 97-112.

Ryan, R. M., \& Deci, E. L. (2000). "Intrinsic and Extrinsic Motivations: Classic Definitions' and New Directions". Contemporary Educational Psychology, 25, 1.

Seweje, R. o. (2010, March 8). Defining Issues in Science Education. 24 ${ }^{\text {th }}$ Inaugural Lecture, University of AdoEkiti.

Shoukat, A., Zubair, H., Fahad, M., Hamid K., Awais, A. (2013). factorsContributing to the Students Academic Performance: A Case Study of Islamia University Sub-Campus. American Journal of Educational Research, $1,(8) 283-289$.

Skinner, B. F. (1974). About Behaviourism. New York: Knopf

Tella, A. (2007). The Impact of Motivation on Students' Academic Achievement and Learning Outcome in Mathematics among Secondary School Students in Nigeria. Eurasia Journal of Mathematics, Science \& Technology, 3(2). 149-156.

Uwadiae, I. (2006). Edo state Statistics of results in WAEC's examination of its senior secondary student's academic achievement. Lagos Nigeria; The West African Examinations Council Research Division. A Paper Delivered at a special West African Examination Council (WAEC) Seminar held in Benin City Nigeria.

Vansteenkiste, M., \& Seonens, B. (2005).antecedents and outcome of Self Motivation in life Domains: Then role of parents and teachers autonomy support. Journal of Youth and Adolesence.34(6),589 - 604.

Williams, R. L. \& Stockdale, S. L. (2004). Classroom Motivation Strategies for Prospective Teacher; The Teacher Educators. London: UZ Publishers.

Yoloye, E. A. (n.d.). Causes of Poor Academic Performance in Northern Nigeria. A Monograph Institute of Education, University of Ibadan. In Tella, A. (2007). The Impact of Motivation on Student's Academic Achievement and Learning Outcomes in Mathematics among Secondary School Students in Nigeria. Eurasia Journal of Mathematics, Science \& Technology Education, 3(3), 149-156. 